\title{
Fight over Maryland monkeys
}

\section{Washington}

IN a move that suggests the government is preparing to take a more aggressive line in defence of research on animals, government-funded scientists last week experimented on and killed one of the 'Silver Spring monkeys', a group of monkeys that has been the focus of animal activist efforts to improve laboratory conditions.

The monkeys became the cause célèbre of the animal rights movement in 1981 , when 17 of them were rescued by police from a laboratory in Silver Spring, Maryland, where they had been kept in inhumane conditions. More than 300 congressmen and senators have since called for the monkeys to be retired to a private sanctuary. The controversy over the treatment of the monkeys has seriously damaged relations between the National Institutes of Health (NIH) and Congress, and has been described by the former NIH director James Wyngaarden as the most enervating case of his tenure.

Edward Taub, the researcher who carried out the initial experiments on the animals at the Silver-Spring-based Institutes for Behavioral Research, was arrested in 1981 and convicted on charges of cruelty, although the ruling was later overturned on a technicality. Taub's NIH grant was subsequently withdrawn and the animals were moved to the Delta Regional Primate Research Center at Tulane University.

'Billy', a crab-eating macaque with two amputated forearms, serious spinal deformity and other injuries, was killed on 14 January after four hours of neurological experiments. The operation came only hours after a US district judge lifted a temporary restraining order on the experiment. The restraining order had been obtained two days earlier by animal rights activists determined to stop NIH from killing any of the Silver Spring monkeys. But in a Sunday morning emergency hearing, NIH officials successfully argued that it was imperative that the research be done before Billy died of illness. In part because of the effects of his deformities, Billy had stopped eating and had lost 10 per cent of his body weight.

Animal protection activists lambasted the experiment, accusing NIH of deceit for repeatedly promising that no "invasive procedures" would be performed on the primates. The Physicians Committee for Responsible Medicine (PCRM) filed a complaint with the Department of Health and Human Service's Office of Scientific Integrity Review last week, calling for an investigation into the research and charging William Raub, the acting director of the National Institutes of Health (NIH) and a party to the decision to experiment on the animal, with "gross scientific mis- conduct." Peter Gerone, principal investigator for the experiment and director of the Delta Center, says that the operation did not violate the "spirit of the agreement" to do no invasive research. "It's not invasive in the sense that we're going to [operate on] the animal and then it's going to regain consciousness", he says.

Although animal activist groups have petitioned NIH to release the monkeys to the care of either of two animal sanctuaries, NIH have so far refused. Agency officials have stated that they do not believe that the proposed sanctuaries can properly care for the monkeys. NIH have meanwhile drafted several proposals for further behavioural and experimental research on the monkeys. Agency officials hope to operate on the rest of the monkeys as their health deteriorates.

Critics say that the monkeys are unsuitable for research and that NIH has concocted the research proposals to avoid turning the animals over to animal protection groups. "It appears that releasing the animals has been viewed by NIH officials as tantamount to surrender", says Neal Barnard, president of PCRM. By experimenting on the animals before they die, he says, NIH hopes to prove that the monkeys did indeed have research value. "NIH needs justification for having kept them so long," Barnard says.

The experiment conducted on Billy sought to determine how the brain reorganizes itself to adapt to the loss of input from nerves elsewhere in the body. Considerable research exists indicating that portions of the brain rendered useless by a nerve injury gradually take over other functions. Further research on the Silver Spring monkeys could help humans with similar injuries, the NIH scientists claim.

But other researchers say the experiment on Billy was unnecessary and poorly planned. "To represent this as science is an affront to science itself," Daniel Robinson, chairman of the Georgetown University psychology department, said at a press conference called by several animalprotection groups. The five-page $\mathrm{NIH}$ experimental protocol includes no control group, has no hypothesis or references, and apparently does not take into consideration the varying - and largely undocumented - experience of the animals in the past eight years.

Carrie Walters, a former University of Vermont neurosurgeon now in private practice, says that very little of what can be learned from the Silver Spring monkeys has a human parallel. "You never see a human patient with a totally deafferented limb", Walters says, referring to the condition where all the nerves to a limb have been severed. Because the animals have been isolated for much of the past eight years and their behaviour was not closely monitored - two important factors in brain adaptation - further research on the animals is likely to be misleading, Walters says. "Bad data is worse than no data", she adds.

The animal-protection advocates said that they would return to the courts to stop further experiments and euthanasia of the seven remaining Silver Spring monkeys.

The latest case also seems likely to renew congressional concern about NIH animal research standards. Roger Galvin, a lawyer for Representative Tom Lantos (Democrat, California) said that the congressman intends to request a congressional oversight hearing on the Delta centre and NIH animal research.

G. Christopher Anderson

\section{AIDS CONFERENCE}

\section{European Parliament backs boycott \\ Paris}

THE European Parliament last week adopted a resolution calling for a boycott of the Sixth International Conference on AIDS, due to be held in San Francisco in June. The move is a protest against current US immigration policy which normally denies entry to aliens found positive for human immunodeficiency virus (HIV). For the AIDS conference, a form of 'laissezpasser' has been proposed by the US authorities, for the duration of the conference, but it requires HIV carriers to register their names.

The resolution, proposed by former French health minister Leon Schwartzenberg on behalf of the Socialist Group, was adopted almost unanimously on a show of hands. It calls on the US government to "abolish this discriminatory measure", while also encouraging scientists in the European Communities not to participate in the conference. It proposes that the organizers "transfer this conference to a country where such discrimination does not take place".

At the end of last year, several nongovernmental organizations, including the League of Red Cross Societies, decided not to attend the June conference. Jonathan Mann, director of the World Health Organisation's AIDS Committee (WHO), has also put pressure on the US authorities to change their immigration policy. But WHO will soon have to decide whether to withdraw its patronage of the conference, because the current restrictions contravene a declaration it adopted in January last year defending the free movement of HIV carriers.

Following the vote in the European Parliament, the French Health Minister, Claude Evin, sent a personal letter to Mann, calling upon WHO to withdraw from the conference. Peter Coles 